\title{
Improvement the firmness of thermal treated black cherry tomatoes (Solanum lycopersicum cv. OG) by low-temperature blanching in calcium chloride solution
}

\author{
1,2,3*Ha, H.T.N. and ${ }^{3}$ Thuy, N.M. \\ ${ }^{1}$ Faculty of Agriculture and Natural Resources, An Giang University, Vietnam \\ ${ }^{2}$ Vietnam National University Ho Chi Minh City, Vietnam \\ ${ }^{3}$ Department of Food Technology, College of Agriculture, Can Tho University, Vietnam
}

\begin{abstract}
Article history:
Received: 23 July 2020

Received in revised form: 24 August 2020

Accepted: 26 September 2020

Available Online: 6

December 2020
\end{abstract}

\section{Keywords:}

Black cherry tomato;

Calcium;

Firmness;

Low-temperature blanching;

Pectin methylesterase

DOI:

https://doi.org/10.26656/fr.2017.5(1).376

\begin{abstract}
The objective of this study was to investigate the effects of low-temperature blanching in calcium chloride $\left(\mathrm{CaCl}_{2}\right)$ solution before high-temperature processing $\left(90^{\circ} \mathrm{C}\right.$ for $\left.1 \mathrm{~min}\right)$ on physicochemical properties related to the texture (total calcium content, pectin methylesterase (PME) activity, and firmness) of black cherry tomatoes (Solanum lycopersicum cv. OG) and to determine the optimum conditions to provide the fruits with the highest firmness. Response Surface Methodology (RSM) was applied to design the experiment with three factors of blanching temperature $\left(52\right.$ to $\left.68^{\circ} \mathrm{C}\right)$, blanching time (12 to 28 mins) and $\mathrm{CaCl}_{2}$ solution concentration (1.2 to $\left.2.8 \% \mathrm{w} / \mathrm{v}\right)$. A sample without lowtemperature treatment was taken as a control. It was found that the blanching of tomatoes at low-temperatures resulted in higher total calcium content and PME activity in tissue after the treatment, and therefore improved the firmness of fruits after high-temperature processing. The highest firmness of treated tomatoes (566.21 g force) was estimated at blanching temperature of $62.05^{\circ} \mathrm{C}$ for 23.09 mins in $2.08 \% \mathrm{CaCl}_{2}$ solution compared to the control which was blanched at high temperature (218 $\mathrm{g}$ force). Under these optimized conditions, the experimental responses (total calcium content, PME activity, and firmness) showed a close agreement with the predicted values.
\end{abstract}

\section{Introduction}

"Black" or "purple" cherry tomatoes are subspecies of Solanum lycopersicum (Zhang et al., 2018) and exhibit a purplish-brown color on their skin (Mes et al., 2008). Black cherry tomatoes contain a variety of bioactive compounds such as lycopene, vitamin $\mathrm{C}$, and also anthocyanin (Li et al., 2011). Because of their health benefits, black cherry tomatoes can be used as a fresh vegetable or processed into many products (Zhang et al., 2018).

An important quality attribute of processed tomatoes is texture. Upon processing, changes in tomato texture are due to changes in structure and chemical composition. The rigid structure of the raw tomato is mainly due to the pectin substances, celluloses, and hemicelluloses. The pectic substances, which are the main constituents of the middle lamella, play a major role in intercellular adhesion and also contribute to the mechanical strength of the cell wall (Abu-Ghannam and Crowley, 2006). Conventional blanching of fruits and vegetables, which is carried out within the range of 80 - $100^{\circ} \mathrm{C}$ for short times to inactivate undesirable enzymes (Abu-Ghannam and Crowley, 2006), is the main pretreatment that precedes further techniques such as drying, canning, and freezing (Ahrné et al., 2003). However, the thermal operations applied in the production of fruits and vegetables frequently result in a significant loss of textural integrity. The most immediate effect of high temperatures is a loss of turgor pressure (Ni et al., 2005). One of the approaches to avoid loss of texture is to use calcium salts, which bind with pectic substances to form calcium pectate, making fruits and vegetables more resistant to acid hydrolysis and thermal softening (Pérez-Alemán et al., 2005). Calcium salts also bind to free carboxylic acid groups along the polygalacturonic acid backbone of the pectin to form cross-links between pectin chains in the middle lamella leads to greater adhesion between cells and a firmer texture (Anthon et al., 2005).

On the other hand, many previous studies which aimed at improving the texture of processed fruits and vegetables also found that preheating them at lowtemperature for a long time (in a so-called low- 
temperature blanching) results in a firmer product through subsequent high-temperature processing (StolleSmits et al., 2000; Ni et al., 2005; Abu-Ghannam and Crowley, 2006). This is due to the activation of enzyme pectin methylesterase (PME) which is present in the cell wall when the fruits and vegetables are soaked in water at a temperature of $50-70^{\circ} \mathrm{C}$ for periods of $15-90 \mathrm{mins}$ (Quintero-Ramos et al., 2002). The beneficial effect on the firmness of processed fruits and vegetables has been observed to intensify if calcium treatment was used in combination with low-temperature blanching (Domínguez et al., 2001; Zhao et al., 2016). PME hydrolyzes the methyl ester linkages in pectin molecules, releasing methanol and free galacturonic acid moieties (Ni et al., 2005). The resulting free carboxyl groups between pectin polymers may then form cross-links through the salt-bridge formation with divalent cations (notably $\mathrm{Ca}^{2+}$ ) naturally present in the tissue or added to the blanching solution (Christiaens et al., 2012). PME also catalyzes a transacylation reaction of the galacturonic acyl groups from methanol to other hydroxyl groups of pectin, resulting in the formation of new ester linkages between pectin molecules and thus contributing to tissue firming ( $\mathrm{Ni}$ et al., 2005). Besides, Anthon et al. (2005) observed that heating diced tomatoes to $70^{\circ} \mathrm{C}$ either before or after the $\mathrm{CaCl}_{2}$ treatment also improved firmness through a subsequent high-temperature treatment, but to a lesser extent than heating during the $\mathrm{CaCl}_{2}$ treatment.

This study was carried out for a new cultivar of black cherry tomato (Solanum lycopersicum cv. OG) grown in Vietnam to evaluate how blanching temperature, time after exposure, and concentration of calcium chloride $\left(\mathrm{CaCl}_{2}\right)$ solution (blanching medium) affected the uptake of calcium, the activity of pectin methylesterase (PME), and the firmness of the whole fruit. Also, the present work identified the conditions of low-temperature blanching at which the firmness of fruits after conventional thermal processing is at optimum value.

\section{Materials and methods}

\subsection{Tomato fruits}

Black cherry tomato (cv. OG) seeds were provided by the F1508 seed store (Ho Chi Minh City, Vietnam) and grown at Nam Long farm, Vinh Long province, Vietnam. Tomatoes were harvested at full ripeness (32 days after fruit formation) corresponding to the diameter of fruits was $25.11 \pm 1.83 \mathrm{~mm}$, the total solid content and $\mathrm{pH}$ value were $6.17 \pm 0.12^{\circ}$ Brix and $4.43 \pm 0.06$, respectively. All fruits with diseases and defects were removed. Fruits were packed into perforated polyvinyl chloride and then cardboard boxes. They were transported to the Food Technology Laboratory of Can Tho University, Vietnam within $1 \mathrm{hr}$. Tomatoes were washed and immersed in ozonated water for 15 mins to kill microorganisms on the surface (using a 2-nozzle ozone generator, model Z755, Vietnam, ozonegenerating of $80.4 \mathrm{mg} / \mathrm{h}$, the sample weight of $1500 \mathrm{~g}$, the ratio of fruits and water was 1:2).

The infiltration process was then carried out in the vacuum equipment (Rocker 400, Laftech, Australia) to increase the thermal conductivity during subsequent blanching due to the replacement of gases inside the fruit spores by the liquid. The vacuum level and treatment time were chosen as $620 \mathrm{mmHg}$ and $22 \mathrm{mins}$, respectively, and a ratio of material and distilled water was 1:1. After vacuum infiltration, the mixture of fruits and water was brought to the atmospheric condition and kept for a further 15 mins. Fruits were drained and used for the blanching experiment with the firmness of $899 \mathrm{~g}$ force, the calcium content of $19.17 \mathrm{mg} / 100 \mathrm{~g}$ fresh material, and the PME activity of $1.22 \mathrm{U} / \mathrm{mL}$.

\subsection{Experimental design}

The low-temperature blanching experiment was designed by the Portable Statgraphics Centurion software (version 15.2.11.0, U.S.A.). The Response Surface Methodology (RSM) with a model of Central Composite Design (CCD) was applied. Blanching temperature $\left(\mathrm{X}_{1}\right)$, time after exposure $\left(\mathrm{X}_{2}\right)$, and $\mathrm{CaCl}_{2}$ (Merck, Germany) concentration in the blanching medium $\left(\mathrm{X}_{3}\right)$ were three independent variables. Before designing the optimization experiment, a preliminary investigation was carried out for a wide range of blanching temperature $\left(50-70^{\circ} \mathrm{C}\right)$, blanching time (10-30 mins), $\mathrm{CaCl}_{2}$ concentration (1$3 \%$ ) and as a result, the narrower study ranges were chosen as $52-68^{\circ} \mathrm{C}, 12-28 \mathrm{mins}$, and $1.2-2.8 \%$. The actual and coded values of each variable were presented in Table 1. Each variable was encoded with five levels: 1.68179, -1 (low), 0 (central), +1 (high) and +1.68179 . The total number of runs was 20, including six replications of the central point. Tomatoes $(1 \mathrm{~kg})$ were put into a stainless steel rectangular mesh basket (a length of $25.5 \mathrm{~cm}$, a width of $10 \mathrm{~cm}$, and a height of 6.5 $\mathrm{cm}$ ) with a square hole size of $0.5 \mathrm{~cm}$ ) and soaked into a thermostatically controlled water bath (Rex C-90, Memmert, Germany) containing $\mathrm{CaCl}_{2}$ solution, in which the ratio of material and $\mathrm{CaCl}_{2}$ solution was 1:2. The preheated samples were then subjected to a second blanching in the water at $90^{\circ} \mathrm{C}$ for 1 min (hightemperature blanching) to inactivate enzymes which can generate undesirable changes in color and odor during subsequent processing and cooled quickly by immersion in cold water $\left(10^{\circ} \mathrm{C}\right)$ for $1 \mathrm{~min}$. The control sample was 
given a single blanching in the water at $90^{\circ} \mathrm{C}$ for $1 \mathrm{~min}$ and then cooled. The total calcium content and PME activity of tomatoes after preheating and the firmness of fruits after high-temperature processing were evaluated.

\subsection{Experimental verification}

After analyzing the data, black cherry tomatoes were treated following the above procedure with selected optimum parameters of low-temperature blanching in triplicate to verify the results under experimental conditions. The responses were measured and compared with the predicted values from the proposed mathematical model.

\subsection{Analytical methods}

\subsubsection{Firmness}

Fruit firmness was determined with a RheoTex (SD 700 , Sun Science, Japan). A $1 \mathrm{~cm}$ - diameter cylindrical probe with a flat end was used in this case. The maximum compression force required to press vertically into the middle of fruits for a $4 \mathrm{~mm}$ travel distance was measured and expressed in $\mathrm{g}$ force, using a constant speed of $1 \mathrm{~mm} / \mathrm{s}$. Five replicates of each sample were carried out and the mean was calculated.

\subsubsection{Pectin methylesterase (PME) activity}

PME activity was determined directly using the method described by Ni et al. (2005). The enzyme was extracted from tomatoes by homogenizing with 2 volumes $(\mathrm{w} / \mathrm{v})$ of $0.2 \mathrm{M} \mathrm{NaCl}$ for $1 \mathrm{~min}$. The mixture was shaken for 30 mins and then filtered through filter paper. A $0.5 \mathrm{~mL}$ of filtrate was mixed with $0.25 \%$ pectin -salt $(0.2 \mathrm{M} \mathrm{NaCl})$ substrate. The mixture was immediately adjusted to $\mathrm{pH} 7.0$ with $0.1 \mathrm{M} \mathrm{NaOH}$. After the initial adjustment, the mixture was shaken and $0.1 \mathrm{M}$ $\mathrm{NaOH}$ was added quantitatively until $\mathrm{pH} 7.0$ was reestablished. The time was measured until the $\mathrm{pH}$ of the mixture regained $\mathrm{pH}$ 7.0. A blank titration was carried out under the same conditions, but $0.5 \mathrm{~mL}$ of $0.2 \mathrm{M} \mathrm{NaCl}$ solution was used instead of the tomatoes filtrate. PME activity was calculated by the equation 1 , where $n$ is the molarity of $\mathrm{NaOH}$ solution, $V_{\mathrm{NaOH}}$ is the volume of $0.1 \mathrm{M}$ $\mathrm{NaOH}$ solution used for titration $(\mathrm{mL}), V_{\text {sample }}$ is the volume of sample ( $\mathrm{mL})$, and $t$ is the titration time (min).

$$
\text { PME }(U / m L)=n \times \frac{V_{\text {NaOH }}}{V_{\text {sample }}} \times t
$$

\subsubsection{Total calcium content}

The total calcium content was determined by the method of precipitate formation with ammonium oxalate (So and Thuan, 1975). The $5 \mathrm{~g}$ of tomato puree was dried in a furnace at $550^{\circ} \mathrm{C}$ until white ash was obtained. The ash was then dissolved in $5 \mathrm{~mL}$ of $20 \% \mathrm{HCl}$ and the solution was filtered through a filter paper. The filtrate was filled to a volume of $100 \mathrm{~mL}$ with distilled water. The diluted filtrate $(25 \mathrm{~mL})$ was added $2 \mathrm{~mL}$ of saturated $\mathrm{NH}_{4} \mathrm{Cl}$ and drop-by-drop of $20 \% \mathrm{NH}_{4} \mathrm{OH}$ until obtaining an alkaline reaction. After filtering out the precipitate, the solution was then added 2 drops of red methyl and acidified with $20 \% \mathrm{CH}_{3} \mathrm{COOH}$ until a light pink color appeared. After boiling, the mixture was added $10 \mathrm{~mL}$ of saturated ammonium oxalate. The mixture was boiled again and cooled to form the precipitate of calcium oxalate. After $1 \mathrm{hr}$, the mixture was filtered through a filter paper. The filter paper containing the precipitate was taken into a conical flask with $25 \mathrm{~mL}$ of $20 \%$ $\mathrm{H}_{2} \mathrm{SO}_{4}$. The mixture was then heated to $80^{\circ} \mathrm{C}$ and titrated with $0.02 \mathrm{~N} \mathrm{KMnO}_{4}$ until a pink color appeared. Total calcium content was calculated using equation 2 , where $K$ is the weight of $\mathrm{Ca}^{2+}$ corresponding to $1 \mathrm{~mL}$ of $\mathrm{KMnO}_{4}(\mathrm{~K}=0.1 \mathrm{mg}) ; n$ is the volume of $\mathrm{KMnO}_{4}$ used for titration; $m$ is the weight of the sample $(\mathrm{g})$.

$$
C a(m g / 100 g)=K \times n \times \frac{100}{25} \times \frac{100}{m}
$$

\subsection{Data analysis}

Experimental data were analyzed by the Portable Statgraphics Centurion software (version 15.2.11.0, U.S.A.). The statistically significant effect of three independent variables (blanching temperature, blanching time, and $\mathrm{CaCl}_{2}$ concentration) on responses was expressed through standardized Pareto charts at the 95\% confidence level (the P-value (probability) less than 0.05). The second-order polynomial equation for predicting the optimum conditions was developed (equation 3), where $Y$ is the predicted response; $\beta_{o}$ is the constant; $\beta_{i}, \beta_{i i}$ and $\beta_{i j}$ are coefficients of the variable for linear, quadratic and interaction terms, respectively; $X_{i}$ and $X_{j}$ were independent variables. The quality of polynomial models was expressed by the coefficient of determination $\left(\mathrm{R}^{2}\right)$ and the P-value of lack-of-fit. The interaction between two variables and responses were obtained in three-dimensional plots and their respective contour plots.

$$
Y=\beta_{o}+\sum_{i=1}^{3} \beta_{i} X_{i}+\sum_{i=1}^{3} \beta_{i i} X_{i}^{2}+\sum_{i=1}^{2} \sum_{j=i+1}^{3} \beta_{i j} X_{i} X_{j}
$$

\section{Results and discussion}

\subsection{Effect of the low-temperature blanching on responses}

The influence of temperature, time, and $\mathrm{CaCl}_{2}$ concentration during low-temperature blanching on the total calcium content, PME activity, and firmness of whole tomato fruit was illustrated in Table 1. The standardized Pareto charts from Figure 1 compared the linear and quadratic effects and interaction on each response. The display order of the bars from top to bottom of charts corresponded to the order of the effect 
Table 1. Total calcium content, PME activity, and firmness of whole tomato fruit at different blanching conditions

\begin{tabular}{|c|c|c|c|c|c|c|}
\hline Run & $\begin{array}{l}\text { Blanching temperature } \\
\qquad\left({ }^{\circ} \mathrm{C}\right)\end{array}$ & $\begin{array}{l}\text { Blanching time } \\
(\mathrm{min})\end{array}$ & $\begin{array}{c}\mathrm{CaCl}_{2} \text { concentration } \\
(\%)\end{array}$ & $\begin{array}{c}\text { Total calcium } \\
\text { content }(\mathrm{mg} / 100 \mathrm{~g})\end{array}$ & $\begin{array}{c}\text { PME activity } \\
(\mathrm{U} / \mathrm{mL})\end{array}$ & $\begin{array}{l}\text { Firmness } \\
\text { (g force) }\end{array}$ \\
\hline 1 & $60(0)$ & $20(0)$ & $2.0(0)$ & 67.71 & 3.75 & 516 \\
\hline 2 & $60(0)$ & $20(0)$ & $2.0(0)$ & 67.41 & 3.72 & 557 \\
\hline 3 & $60(0)$ & $20(0)$ & $2.0(0)$ & 67.22 & 3.71 & 550 \\
\hline 4 & $60(0)$ & $12(-1.68179)$ & $2.0(0)$ & 65.78 & 2.18 & 435 \\
\hline 5 & $60(0)$ & $20(0)$ & $2.8(+1.68179)$ & 66.16 & 2.25 & 447 \\
\hline 6 & $65(+1)$ & $15(-1)$ & $1.5(-1)$ & 69.36 & 3.43 & 459 \\
\hline 7 & $68(+1.68179)$ & $20(0)$ & $2.0(0)$ & 77.36 & 3.84 & 464 \\
\hline 8 & $52(-1.68179)$ & $20(0)$ & $2.0(0)$ & 59.18 & 1.71 & 232 \\
\hline 9 & $60(0)$ & $20(0)$ & $2.0(0)$ & 66.96 & 3.67 & 545 \\
\hline 10 & $65(+1)$ & $25(+1)$ & $1.5(-1)$ & 72.19 & 3.71 & 484 \\
\hline 11 & $60(0)$ & $28(+1.68179)$ & $2.0(0)$ & 66.57 & 2.56 & 551 \\
\hline 12 & $55(-1)$ & $25(+1)$ & $1.5(-1)$ & 62.29 & 1.79 & 374 \\
\hline 13 & $65(+1)$ & $15(-1)$ & $2.5(+1)$ & 73.26 & 2.75 & 515 \\
\hline 14 & $55(-1)$ & $15(-1)$ & $2.5(+1)$ & 62.66 & 1.88 & 291 \\
\hline 15 & $65(+1)$ & $25(+1)$ & $2.5(+1)$ & 74.24 & 2.86 & 499 \\
\hline 16 & $60(0)$ & $20(0)$ & $2.0(0)$ & 66.84 & 3.63 & 542 \\
\hline 17 & $55(-1)$ & $15(-1)$ & $1.5(-1)$ & 59.45 & 1.94 & 275 \\
\hline 18 & $60(0)$ & $20(0)$ & $2.0(0)$ & 66.32 & 3.58 & 536 \\
\hline 19 & $55(-1)$ & $25(+1)$ & $2.5(+1)$ & 63.01 & 1.91 & 404 \\
\hline 20 & $60(0)$ & $20(0)$ & $1.2(-1.68179)$ & 63.54 & 2.94 & 407 \\
\hline \multicolumn{4}{|c|}{ Control } & 19.17 & 1.22 & 218 \\
\hline
\end{tabular}

Numbers in parentheses were coded values.

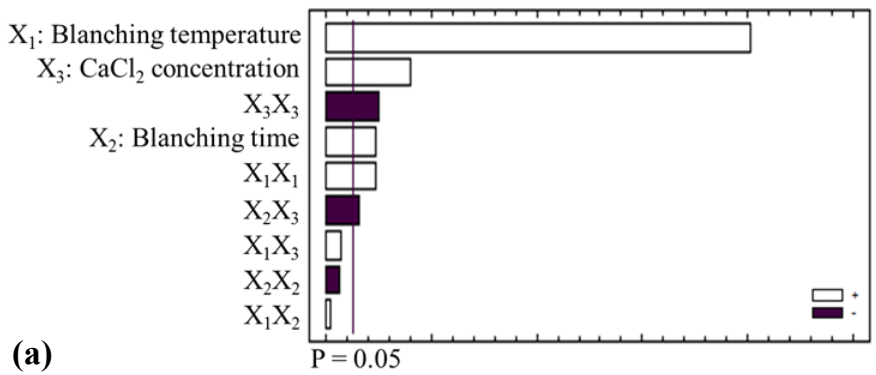

levels from the strongest to the weakest. A blue vertical line on charts indicated the statistical significance limit which corresponded to the $95 \%$ confidence $(\mathrm{P}=0.05)$. An effect was considered to be significant when the variable horizontal bar crossed this vertical line. It could be seen that all studied variables (blanching temperature, blanching time, and $\mathrm{CaCl}_{2}$ concentration) had a marked linear effect on total calcium content, PME, and firmness because the P-values were lower than 0.05 , in which,
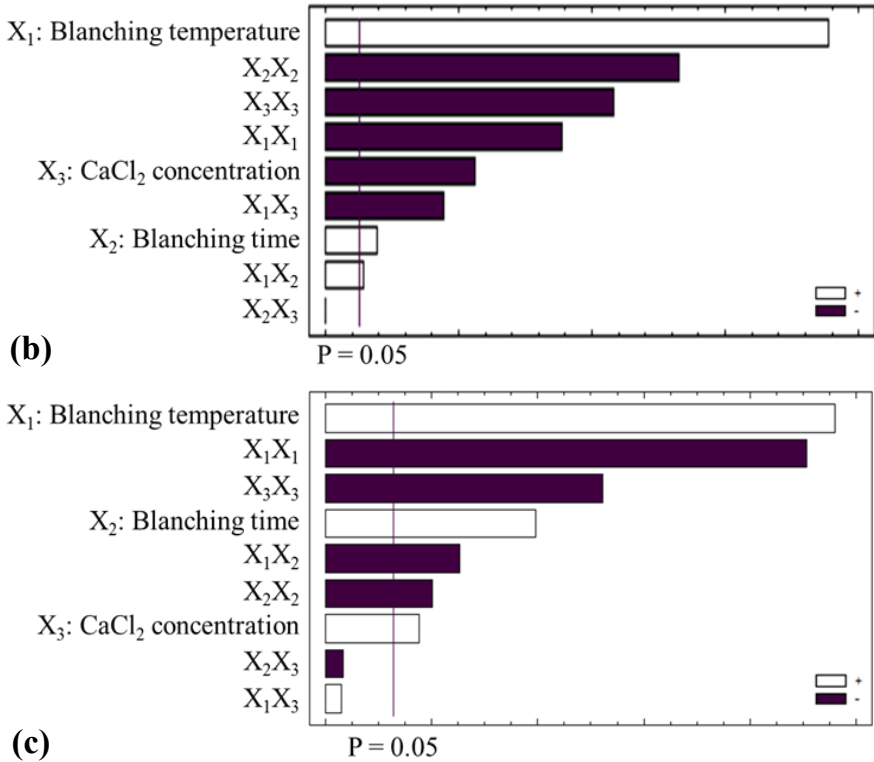

Figure 1. Standardized Pareto charts of effects for responses of (a) total calcium content (mg/100 g), (b) PME activity (U/ $\mathrm{mL}$ ), (c) firmness ( $\mathrm{g}$ force)

\subsection{Predicted models for responses}

The mathematic formulations expressing the relationship between the predicted responses and three independent variables were established (from Equation 4 to 6 in Table 2). The coefficient of determination (Rsquared $-\mathrm{R}^{2}$ ), which indicated the percentage of variability that the chosen model explained in every response, was used to assess the model satisfactoriness. The adjusted R-squared value was more suitable for comparing models with different numbers of independent variables. The models were considered to be fitted with experimental data when the $\mathrm{R}^{2}$ reached at least 0.8 (Guan and Yao, 2008) and this value close to 1 was desirable. In these responses, adequate agreements were obtained between empirical and predicted data from second-order models, which were indicated by high correlation coefficient values $\left(\mathrm{R}^{2}>0.98\right)$. This would be 
Table 2. Regression equations in terms of coded variables to predict the responses

\begin{tabular}{|c|c|c|c|c|c|}
\hline Responses & Equations & & $\mathrm{R}^{2}$ & $\begin{array}{c}\mathrm{R}^{2} \\
\text { (adjusted for d.f) }\end{array}$ & $\begin{array}{c}\text { P-value } \\
\text { (lack-of-fit) }\end{array}$ \\
\hline $\begin{array}{l}\text { Total calcium } \\
\text { content } \\
(\mathrm{mg} / 100 \mathrm{~g})\end{array}$ & $\begin{array}{l}Y_{1}=81.8639-2.28551 X_{1}+0.65013 X_{2}+11.4679 X_{3}+ \\
0.02583 X_{1}^{2}+0.0031 X_{1} X_{2}+0.101 X_{1} X_{3}-0.0069 X_{2}^{2}- \\
0.217 X_{2} X_{3}-2.76069 X_{3}^{2}\end{array}$ & (4) & 0.9876 & 0.9765 & 0.1005 \\
\hline $\begin{array}{l}\text { PME activity } \\
(\mathrm{U} / \mathrm{mL})\end{array}$ & $\begin{array}{l}Y_{2}=-69.7202+1.76383 X_{1}+0.62056 X_{2}+10.5731 X_{3}- \\
0.0127 X_{1}^{2}+0.00255 X_{1} X_{2}-0.0795 X_{1} X_{3}-0.01903 X_{2}^{2}+ \\
0.0005 X_{2} X_{3}-1.55138 X_{3}^{2}\end{array}$ & (5) & 0.9903 & 0.9815 & 0.0528 \\
\hline $\begin{array}{l}\text { Firmness } \\
\text { (g force) }\end{array}$ & $\begin{array}{l}Y_{3}=-13088+382.627 X_{1}+95.7812 X_{2}+651.922 X_{3}- \\
2.9152 X_{1}^{2}-1.015 X_{1} X_{2}+1.25 X_{1} X_{3}-0.64958 X_{2}^{2}- \\
1.35 X_{2} X_{3}-168.083 X_{3}^{2}\end{array}$ & (6) & 0.9891 & 0.9794 & 0.5133 \\
\hline
\end{tabular}

Notes: $\mathrm{X}_{1}$ was blanching temperature $\left({ }^{\circ} \mathrm{C}\right), \mathrm{X}_{2}$ was blanching time $(\mathrm{min}), \mathrm{X}_{3}$ was $\mathrm{CaCl}_{2}$ concentration $(\%)$

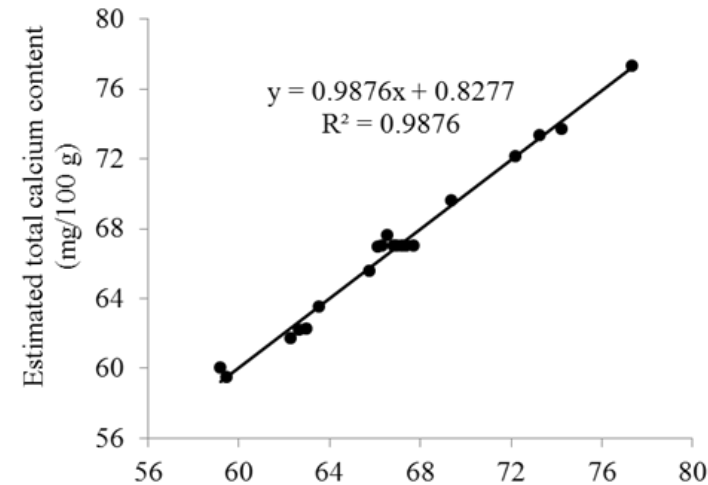

(a)

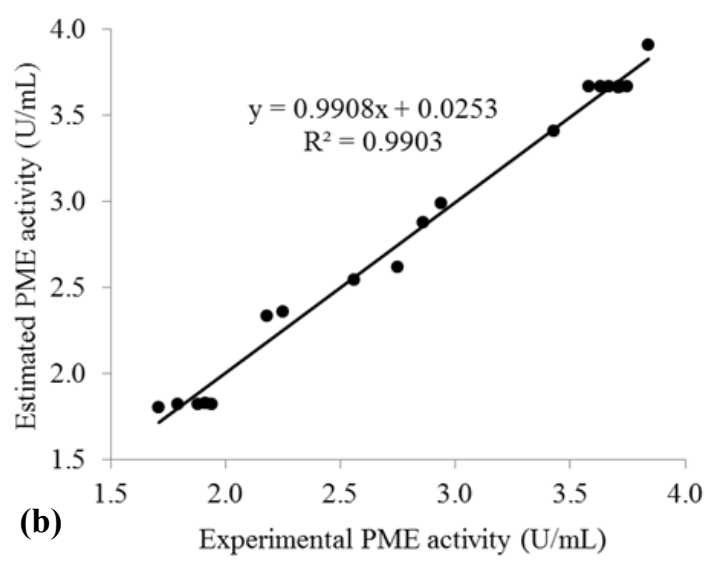

(b) $\quad$ Experimental PME activity $(\mathrm{U} / \mathrm{mL})$

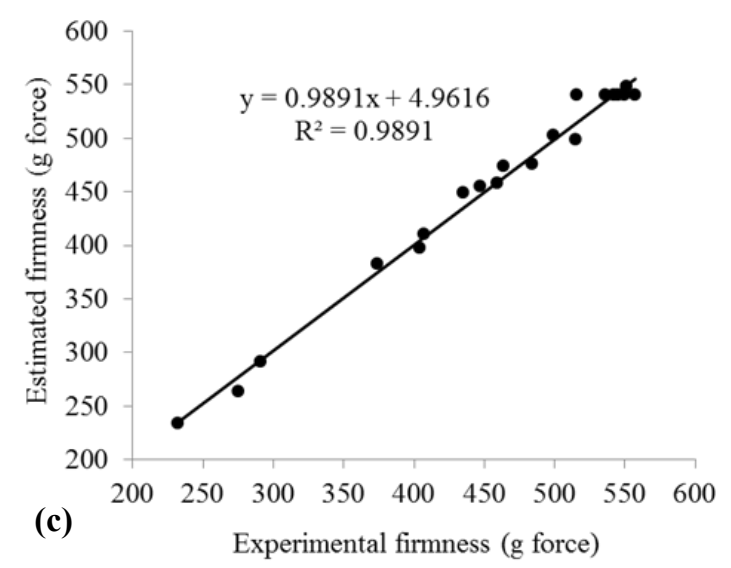

Figure 2. Correlation between the experimental and estimated values for responses of (a) total calcium content, (b) PME activity and (c) firmness.

illustrated clearly by the scatter plots of the estimated versus experimental values (Figure 2). Besides, the test for lack-of-fit was carried out by comparing the variability of the model residuals to the variability between observations to check whether the chosen model was adequate to describe the experimental data. Since the P-values for lack-of-fit were greater than 0.05 , the developed models appeared to be fitted to the observed data at the $95 \%$ confidence level and could be applied to predict the change of process responses based on three variables with high accuracy.

\subsection{Response surfaces and contour plots for responses}

The response surfaces and contour plots of blanching conditions were shown in Figures 3, 4, and 5. The twodimensional representation of the responses on every two -variables plane (contour plot) showed concentrically closed curves whose centers represented the optimum conditions.

As can be seen from Figure 3, the calcium absorption increased as the blanching temperature, blanching time, and $\mathrm{CaCl}_{2}$ concentration in the blanching medium increased. Such behavior was in agreement with the observations during low-temperature blanching of carrot slices (Quintero-Ramos et al., 2002) and Jalapeno pepper (Pérez-Alemán et al., 2005) in calcium chloride solution. This has been due to the alteration of cell wall permeability that is related to the mass transfer of calcium in the tissue, and also to a possible reaction of calcium ions with free carboxylic groups coming from the de-esterification of pectins in the process (Pérez- 

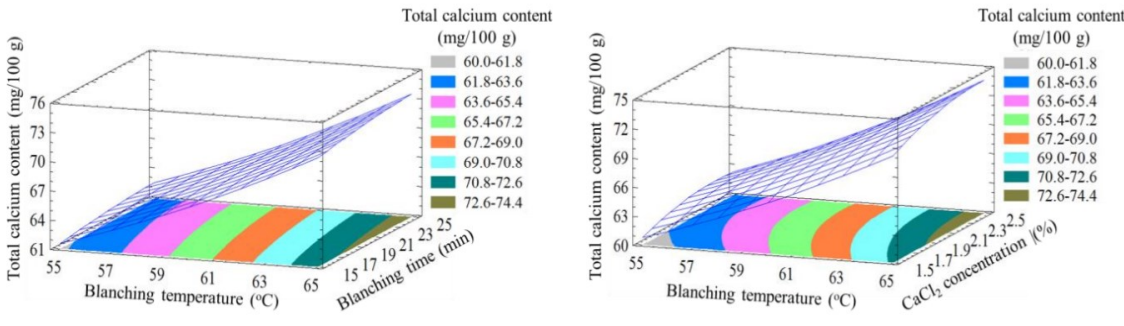

a. Effect of blanching temperature and time ( $\mathrm{CaCl}_{2}$ concentration of $2.0 \%$ )

b. Effect of blanching temperature and $\mathrm{CaCl}_{2}$ concentration (blanching time of $20 \mathrm{~min}$ ) Total calcium content

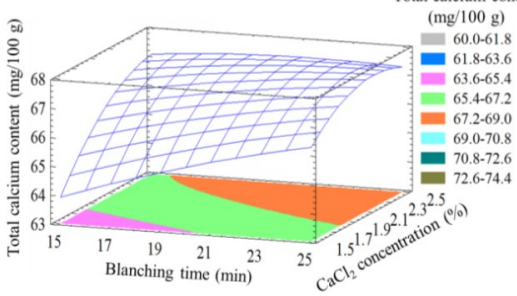

c. Effect of blanching time and $\mathrm{CaCl}_{2}$ concentration (blanching temperature of $60^{\circ} \mathrm{C}$ )

Figure 3. Response surface and contour plots for the effect of low-temperature blanching variables on the total calcium content of tomatoes after treatment
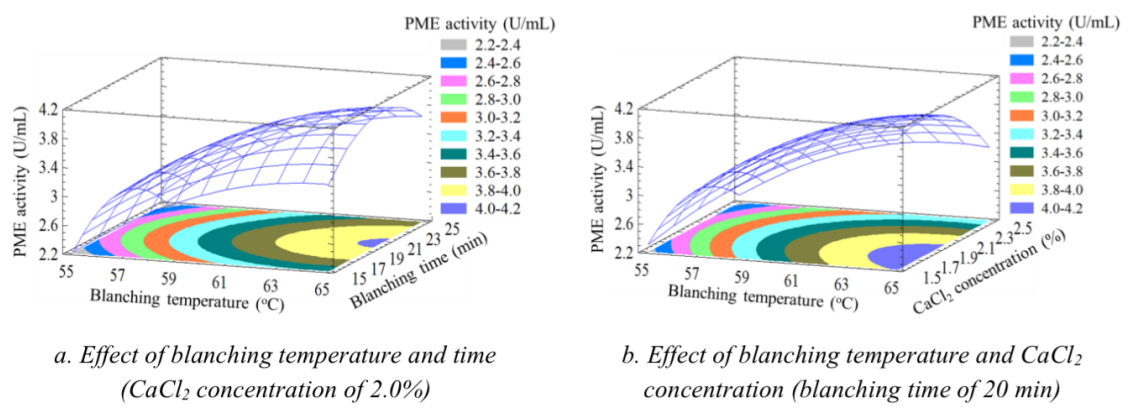

b. Effect of blanching temperature and $\mathrm{CaCl}_{2}$ concentration (blanching time of $20 \mathrm{~min}$ )

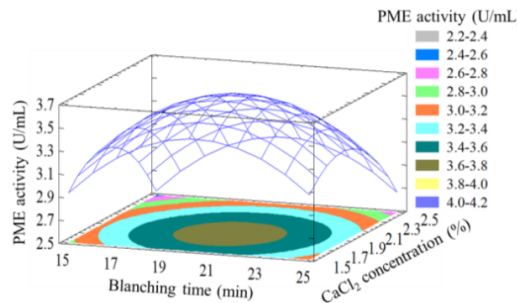

c. Effect of blanching time and $\mathrm{CaCl}_{2}$ concentration (blanching temperature of $60^{\circ} \mathrm{C}$ )

Figure 4. Response surface and contour plots for the effect of low-temperature blanching variables on the PME activity of tomatoes after treatment
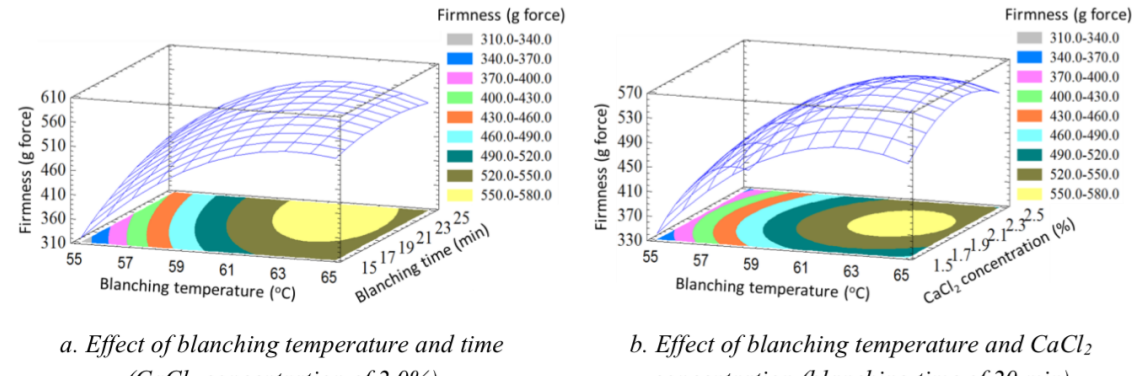

( $\mathrm{CaCl}_{2}$ concentration of $2.0 \%$

b. Effect of blanching temperature and $\mathrm{CaCl}_{2}$ concentration (blanching time of $20 \mathrm{~min}$ )

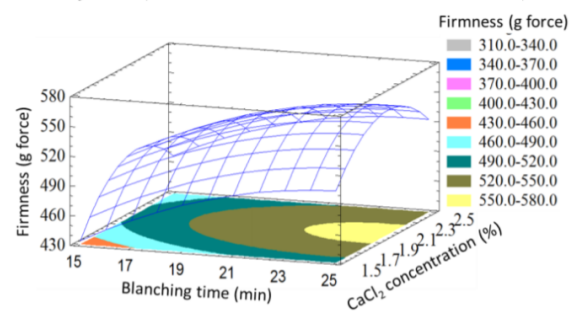

c. Effect of blanching time and $\mathrm{CaCl}_{2}$ concentration (blanching temperature of $60^{\circ} \mathrm{C}$ )

Figure 5. Response surface and contour plots for the effect of low-temperature blanching variables on the firmness of tomatoes after high-temperature processing 
Alemán et al., 2005). The optimum conditions (blanching temperature of $68^{\circ} \mathrm{C}$, a blanching time of 26.58 mins, and a $\mathrm{CaCl}_{2}$ concentration of $2.28 \%$ ) resulted in the highest total calcium content in the tissue $(78.20 \mathrm{mg} / 100 \mathrm{~g})$ (Table 3), which was significantly higher $(\mathrm{P}<0.05)$ than those treated at $90^{\circ} \mathrm{C}$ for $1 \mathrm{~min}$ without blanching $(19.17 \mathrm{mg} / 100 \mathrm{~g})$. After the increase in a blanching time of 15 to $26.58 \mathrm{mins}$ and a concentration range of 1.5 to $2.28 \% \mathrm{CaCl}_{2}$, very little additional calcium content was observed.

It was evident that low-temperature blanching improved the PME activity of tomatoes after blanching (Figure 4). Optimum activities reported for PME in different studies varies due to variations in composition and variety, however, all reported values lie in the range of $50-70^{\circ} \mathrm{C}$ (Abu-Ghannam and Crowley, 2006). The effects of calcium and other cations on PME activity are through the interactions of the cations with the pectin substrate rather than a direct effect on the PME enzyme. As PME de-esterifies the pectin, the number of free carboxyl groups in the pectin increases, causing the enzyme to become tightly bound to the pectin and thus inactive. Added cations such as calcium compete for these binding sites, reducing the binding of the enzyme to the pectin, and allowing for additional deesterification to occur (Anthon et al., 2005). Calcium also inhibits polygalacturonase activity, therefore, if heating is done in the absence of calcium, some of the de -esterified pectins will be cleaved by polygalacturonase activity, reducing cell wall strength and thus decrease firmness (Anthon et al., 2005).

Optimum activity for PME in this study $(4.13 \mathrm{U} / \mathrm{mL})$ was observed at $66.15^{\circ} \mathrm{C}$ after a 20.76 mins blanching period in $1.72 \% \mathrm{CaCl}_{2}$ solution (Table 3 ). However, further increases in these variables produce a decrease in the activity of this enzyme. Partial inactivation of PME would explain why the measured activity was lower at higher temperatures and longer times. As we have shown previously, in tomato juice, thermal inactivation of PME becomes significant at temperatures above $70^{\circ} \mathrm{C}$ (Anthon et al., 2002). The activity of PME, purified from tomatoes and acting on pure pectin, was known to be increased by added calcium, but with a narrow optimum above which additional calcium inhibits (Lee and Macmillan, 1968). Increasing the level of PME activity could increase the number of calcium-binding sites in the pectins and thus allow for increased calcium crosslinking and a better texture (Anthon et al., 2005).

Upon investigating the effect that blanching temperatures used had on the texture of potatoes, AbuGhannam and Crowley (2006) found that samples blanched at $65^{\circ} \mathrm{C}$ and treated at $100^{\circ} \mathrm{C}$ for 25 mins gave a higher firmness than those blanched at $75^{\circ} \mathrm{C}$ and then treated at $100^{\circ} \mathrm{C}$ for $25 \mathrm{mins}$, however, when the texture was measured after blanching, i.e. before processing, there was no significant difference between shear force values for 65 and $75^{\circ} \mathrm{C}$. It would appear that the firming effect of low temperature blanching only becomes evident after the subsequent thermal processing. A similar finding was achieved by Ni et al. (2005) whereby the firmness of cabbage, green bell peppers, sugar snap peas, carrot, and broccoli were enhanced when processing was preceded by a blanching step. Therefore, in this study, the firmness of fruits was also determined after the conventional blanching (as would be carried out in the industry).

The firmness of fruits also increased as the experimental conditions were elevated (Figure 5). The maximum value of $566.21 \mathrm{~g}$ was reached at a blanching temperature of $62.05^{\circ} \mathrm{C}$ for 23.09 mins in $2.08 \% \mathrm{CaCl}_{2}$ solution (Table 3). The experimental conditions above these values produced a decrease in the firmness. The maximum firmness was 2.61 times higher than the control sample ( $218 \mathrm{~g}$ force). The firming effect resulting from a low-temperature treatment may be attributed to the stimulation of enzyme pectin methylesterase (PME), which is activated at temperatures between 50 and $70^{\circ} \mathrm{C}$ (Ni et al., 2005) coupled with the increased cross-linking to produce insoluble pectate from the calcium absorbed during the blanching (Quintero-Ramos et al., 2002). However, the change in the firmness was not as great as those obtained with calcium absorption, which indicated that an excess of calcium ions in the fruits did not improve the firmness significantly. These results exhibited a similar trend to those reported by QuinteroRamos et al. (2002) for carrots and Pérez-Alemán et al. (2005) for jalapeño pepper.

Each response reached the optimum value under different blanching conditions. However, as indicated in the objective, the firmness should be as high as possible, therefore, this study chose the optimum conditions of a

Table 3. Optimum conditions of low-temperature blanching for each response

\begin{tabular}{lcccc}
\hline & & \multicolumn{3}{c}{ Optimum conditions } \\
\cline { 3 - 5 } \multicolumn{1}{c}{ Responses } & Optimum value & $\begin{array}{c}\text { Blanching } \\
\text { temperature }\left({ }^{\circ} \mathrm{C}\right)\end{array}$ & $\begin{array}{c}\text { Blanching } \\
\text { time }(\mathrm{min})\end{array}$ & $\begin{array}{c}\mathrm{CaCl}_{2} \\
\text { concentration }(\%)\end{array}$ \\
\hline Total calcium content $(\mathrm{mg} / 100 \mathrm{~g})$ & 78.2 & 68 & 26.58 & 2.28 \\
PME activity $(\mathrm{U} / \mathrm{mL})$ & 4.13 & 66.76 & 20.76 & 1.72 \\
Firmness (g force) & 566.21 & 62.05 & 23.09 & 2.08 \\
\hline
\end{tabular}


blanching temperature of $62.05^{\circ} \mathrm{C}$ for 23.09 mins in $2.08 \% \mathrm{CaCl}_{2}$ solution Under these conditions, the firmness of $566.21 \mathrm{~g}$ force after high-temperature processing with the total calcium content of 69.74 $\mathrm{mg} / 100 \mathrm{~g}$ fresh fruits and the PME activity of $3.70 \mathrm{U} / \mathrm{mL}$ after blanching was predicted.

\subsection{Empirical validation of the predicted models}

The obtained results were finally verified. With optimum conditions selected, the experimental firmness, total calcium content, and PME activity were $563.26 \mathrm{~g}$ force, $69.56 \mathrm{mg} / 100 \mathrm{~g}$, and $3.81 \mathrm{U} / \mathrm{mL}$, respectively. These results confirmed that experimental values were in agreement with the predicted values, thus the models were validated.

\section{Conclusion}

The low-temperature treatment for longer time in $\mathrm{CaCl}_{2}$ solution which applied for black cherry tomatoes (cv. OG) resulted in higher total calcium content and PME activity of whole fruit after soaking. Consequently, the firmness of tomatoes was improved after blanching at $90^{\circ} \mathrm{C}$ for $1 \mathrm{~min}$ as compared to conventional blanching alone. The high value of firmness of fruit was attributed to the combined action of PME and the addition of calcium. The response surface methodology was effective in the optimization of tomatoes treatment. The maximum firmness was $566.21 \mathrm{~g}$ force (only reduced $37 \%$ ) compared to $217 \mathrm{~g}$ force of control sample (reduced 76\%) from the initial value of $899 \mathrm{~g}$. The second-order polynomial models for the responses were verified experimentally and provided a satisfactory fit.

\section{Conflict of interest}

The authors declare no conflict of interest.

\section{References}

Abu-Ghannam, N. and Crowley, H. (2006). The effect of low-temperature blanching on the texture of whole processed new potatoes. Journal of Food Engineering, 74(3), 335-344. https:// doi.org/10.1016/j.jfoodeng.2005.03.025

Ahrné, L., Prothon, F. and Funebo, T. (2003). Comparison of drying kinetics and texture effects of two calcium pretreatments before microwaveassisted dehydration of apple and potato. International Journal of Food Science and Technology, 38(4), 411-420. https://doi.org/10.1046/ j.1365-2621.2003.00712.x

Anthon, G. E., Blot, L. and Barrett, D.M. (2005). Improved firmness in calcified diced tomatoes by temperature activation of pectin methylesterase. Journal of Food Science, 70(5), C342-C347. https://doi.org/10.1111/j.13652621.2005.tb09964.x

Anthon, G.E., Sekine, Y., Watanabe, N. and Barrett, D.M. (2002). Thermal inactivation of pectin methylesterase, polygalacturonase, and peroxidase in tomato juice. Journal of Agricultural and Food Chemistry, 50(21), 6153-6159. https:// doi.org/10.1021/jf020462r

Christiaens, S., Van Buggenhout, S., Houben, K., Chaula, D., Van Loey, A.M. and Hendrickx, M.E. (2012). Unravelling process-induced pectin changes in the tomato cell wall: An integrated approach. Food Chemistry, 132(3), 1534-1543. https://doi.org/10.1016/j.foodchem.2011.11.148

Domínguez, R., Quintero-Ramos, A., Bourne, M., Barnard, J., Talamás-Abbud, R., Jiménez-Castro, J. and Anzaldúa-Morales, A. (2001). Texture of rehydrated dried bell peppers modified by lowtemperature blanching and calcium addition. International Journal of Food Science and Technology, 36(5), 523-527. https://doi.org/10.1046/ j.1365-2621.2001.00493.x

Guan, X. and Yao, H. (2008). Optimization of Viscozyme L-assisted extraction of oat bran protein using response surface methodology. Food Chemistry, 106(1), 345-351. https://doi.org/10.1016/ j.foodchem.2007.05.041

Lee, M. and Macmillan, J.D. (1968). Mode of action of pectic enzymes. I. Purification and certain properties of tomato pectinesterase. Biochemistry, 7(11), 40054010. https://doi.org/10.1021/bi00851a030

Li, H., Deng, Z., Liu, R., Young, J.C., Zhu, H., Loewen, S. and Tsao, R. (2011). Characterization of phytochemicals and antioxidant activities of a purple tomato (Solanum lycopersicum L.). Journal of Agricultural and Food Chemistry, 59(21), 1180311811. https://doi.org/10.1021/jf202364v

Mes, P.J., Boches, P., Myers, J.R. and Durst, R. (2008). Characterization of tomatoes expressing anthocyanin in the fruit. Journal of the American Society for Horticultural Science, 133(2), 262-269. https:// doi.org/10.21273/JASHS.133.2.262

Ni, L., Lin, D. and Barrett, D.M. (2005). Pectin methylesterase catalyzed firming effects on lowtemperature blanched vegetables. Journal of Food Engineering, 70(4), 546-556. https:// doi.org/10.1016/j.jfoodeng.2004.10.009

Pérez-Alemán, R., Márquez-Meléndez, R., MendozaGuzmán, V., Jiménez-Castro, J., Torre, L.D.L., Rodríguez-Terrazas, B., Barnard, J. and QuinteroRamos, A. (2005). Improving textural quality in 
frozen jalapeño pepper by low-temperature blanching in calcium chloride solution. International Journal of Food Science and Technology, 40(4), 401 -410 . https://doi.org/10.1111/j.13652621.2004.00937.x

Quintero-Ramos, A., Bourne, M., Barnard, J., GonzálezLaredo, R., Anzaldúa-Morales, A., PensabenEsquivel, M. and Márquez-Meléndez, R. (2002). Low-temperature blanching of frozen carrots with calcium chloride solutions at different holding times on texture of frozen carrots. Journal of Food Processing and Preservation, 26(5), 361-374. https://doi.org/10.1111/j.1745-4549.2002.tb00490.x

So, P.V. and Thuan, B.T.N. (1975). Analysis of food and foodstuffs. Scientific and Technical Publisher.

Stolle-Smits, T., Beekhuizen, J.G., Recourt, K., Voragen, A.G. and van Dijk, C. (2000). Preheating effects on the textural strength of canned green beans. 1. Cell wall chemistry. Journal of Agricultural and Food Chemistry, 48(11), 5269-5277. https:// doi.org/10.1021/jf990941z

Zhang, W., Xie, F., Lan, X., Gong, S. and Wang, Z. (2018). Characteristics of pectin from black cherry tomato waste modified by dynamic high-pressure microfluidization. Journal of Food Engineering, 216, 90-97. https://doi.org/10.1016/ j.jfoodeng.2017.07.032

Zhao, W., Xie, W., Du, S., Yan, S., Li, J. and Wang, Q. (2016). Changes in physicochemical properties related to the texture of lotus rhizomes subjected to heat blanching and calcium immersion. Food Chemistry, 211, 409-414. https://doi.org/10.1016/ j.foodchem.2016.05.075 